\title{
Assessment of Fraction and Mobility of Arsenic in Soil Near the Mine Waste Dam
}

\author{
Min-Suk Kim ${ }^{1}\left(\mathbb{D}\right.$, Sang-Hwan Lee ${ }^{2}$ and Jeong-Gyu Kim ${ }^{1,3, * \mathbb{C}}$ \\ 1 O-Jeong Eco-Resilience Institute, Korea University, Seoul 02841, Korea; adoniss86@korea.ac.kr \\ 2 Technical Research Institute, Mine Reclamation Corporation, Wonju 26464, Korea; soillsf@mireco.or.kr \\ 3 Division of Environmental Science and Ecological Engineering, College of Life Science and Biotechnology, \\ Korea University, Seoul 02841, Korea \\ * Correspondence: lemonkim@korea.ac.kr; Tel.: +82-2-3290-3474
}

Received: 26 December 2019; Accepted: 14 February 2020; Published: 17 February 2020

check for updates

\begin{abstract}
Arsenic (As) contamination in abandoned mining areas has been of concern in Korea; hence, the reclamation and restoration of these areas must be conducted. Since large contaminated areas have not been restored yet, post management of restoration sites would be insufficient. The aim of this study was to monitor the pollution of environments near the waste dam in mining areas and to assess the fraction and mobility of As. Chemical assessment was conducted using sequential extraction and single extraction methods [Mehlich-3, $1 \mathrm{~N} \mathrm{HCl}$, the simple bioavailability extraction test (SBET), and the synthetic precipitation leaching procedure (SPLP)], whereas biological assessment was conducted with a bok choy (Brassica campestris L. ssp. chinensis Jusl.) cultivation experiment. The results showed that the waste rock soil, forest soil, and sediments near the dam were contaminated with As. As a result of sequential extraction, most of the As in the soil of the upper part of the dam were observed to be tightly adsorbed (well-crystallized hydrous metal oxides and residual phases), whereas As in the forest soil of the lower part of the dam were observed to be relatively weakly bound (amorphous and poorly-crystallized hydrous metal oxides). These results show that As could be re-dissolved from secondary contaminated forest soil and spread to nearby environments. For the sustainable management of soil environment, an assessment of the fraction and mobility of As coupled with continuous monitoring are required.
\end{abstract}

Keywords: bioavailability; mine waste dam; post-management; reclamation; rootage

\section{Introduction}

There are more than 5400 mines in Korea, more than $85 \%$ of which are abandoned and continuously pollute the surrounding environments over a long period of time [1]. In Korea, there have been a number of indiscriminate gold mine developments in the past; therefore, the distribution and consumption of contaminated crops produced in such a polluted environment can be a major threat to public health [2]. Gold and arsenic (As) coexist and are similar in mineralogy; therefore, arsenic contamination is a common environmental problem [3]. As leaches and diffuses from mine drainage, mine waste rock, and mine tailings to surrounding environments. Continuous intake of As leads to its accumulation in the human body, thereby affecting the body system (integumentary, nervous, respiratory, cardiovascular, hematopoietic, immune, endocrine, hepatic, renal, and reproductive) through multiple pathways [4]. It is well known that the mobility and bioavailability of As in the environment is affected by various factors such as $\mathrm{pH}$, redox condition, dissolved organic carbon (DOC), clay content, and iron/manganese/aluminum-metal oxides, among others [3,5]. In order to reduce the risk to the environment and human health, an acid mine drainage treatment facility and prevention dam have been constructed [6,7]. 
In abandoned mining areas, the dam is one of several work plans to aid recovery, including enclosure, isolation, encapsulation, and chemical/physical/biological treatment. In addition, there are at least 3500 dams worldwide for the treatment of tailings; these dams cover a wide area, ranging from several hectares to several thousands of hectares [8,9]. In Korea, since mountains constitute $65 \%$ of the landmass, dams are installed to prevent the loss of topsoil by landslides, as well as the storage and loss of mine tailings $[10,11]$. However, most of the dams in abandoned mining areas are not enclosed and are therefore directly exposed to weathering [12]. Gao and Bradshaw [13] estimated the loads of $\mathrm{Cd}, \mathrm{Pb}$, and $\mathrm{Zn}$ flowing into the Conwy stream in North Wales; heavy metals were found to be actively dispersed and deposited annually from the Parc Mine. Considering the discharges $\left(\mathrm{m}^{3}\right.$ $\mathrm{s}^{-1}$ ) and metal concentration $\left(\mathrm{mg} \mathrm{L}^{-1}\right)$, their respective loads were compared among pre-reclamation (1977), post-reclamation (1978), and the present (1992). In November 1977, an application of the stabilization method led to a reduction in the metal load, however, metal inflows due to rainfall could not be blocked fundamentally. Fosso-Kankeu et al. [14] reported the importance of dam design and management by analyzing the metal speciation of tailings leachate using artificial rainfall. In Korea, the average annual precipitation is $1245 \mathrm{~mm}$, which is more than 1.4 times the world average of 880 $\mathrm{mm}$. However, more than $70 \%$ of rainfall occur in the summer, therefore, the loss of topsoil is still a current problem [15]. This also affects waste-rock dams in abandoned mining areas with a possibility of causing secondary pollution, due to the movement and spread of pollutants. Korea's abandoned mines, which are distributed nationwide, have been continuously reclaimed and restored since the 1990s; however, there are still many sites which are yet to be restored [16]. In Korea, the Mine Reclamation Corporation (MIRECO) had conducted complete research on post monitoring and stability evaluation of mine waste loss prevention sites for 21 projects from 2012 to 2016 [17]. However, few numbers of survey points were considered, and the focus on structural stability of the facility did not reflect the impact on the surrounding environments. Due to the difficulty in carrying out post-management of the restored area, researches on the effects of the restoration facility on the surrounding environments could be hard to find.

When conducting post-monitoring of restored areas, it is necessary to understand the behavior of As in the environment. In oxic soil condition, As mainly exists as arsenate (V)-its main chemical species. This is because As is characterized by being present in an anionic form in combination with oxygen, unlike cationic heavy metals (cadmium, zinc, copper, and lead, among others) that exist in an independent anionic form [3,18]. Of the arsenate species, only $\mathrm{H}_{2} \mathrm{AsO}_{4}{ }^{-}$increases with a rise in soil $\mathrm{pH}$ (within $3<$ soil $\mathrm{pH}<6$ ), and exist in the soil at a $\mathrm{pH}$ between 8 and 11 [19,20]. Well known factors affecting the behavior of As are $\mathrm{pH}$, DOC, clay contents, metal oxides, and the presence of competing ionic species including phosphorous and silicates $[3,21,22]$. The mobility of As in the soil increases with a corresponding increase in DOC content and soil $\mathrm{pH}$; however, adsorption is a major mechanism that decreases this mobility $[3,23]$. Soil colloids and metal oxides are major adsorption sites for As, and many studies have focused on amorphous iron hydroxides [21]. In the process of oxidizing $\mathrm{Fe}$, amorphous Fe oxides are formed. In addition, As could be easily and quickly adsorbed to amorphous Fe through the ligand exchange of As for the $\mathrm{OH}^{-}$and $\mathrm{OH}_{2}$ groups [20,24,25]. Therefore, it is necessary to consider the bound form of As besides the total concentration of As in order to evaluate the contamination status of the monitoring site.

In terms of post monitoring, the aim of this study is to assess the fraction, mobility, and bioavailability of As in an abandoned mining area where the dam to prevent loss in mine waste was installed 20 years ago.

\section{Materials and Methods}

\subsection{Site Description}

The Gilgok mine located in Hongcheon, Gangwon-do, South Korea was selected as the abandoned mining area. It was difficult to find the exact location of the tunnel; records however indicated that 
there were two mining tunnels. In addition, there was a huge dump of mine waste in the vicinity of the tunnel (Figure 1).

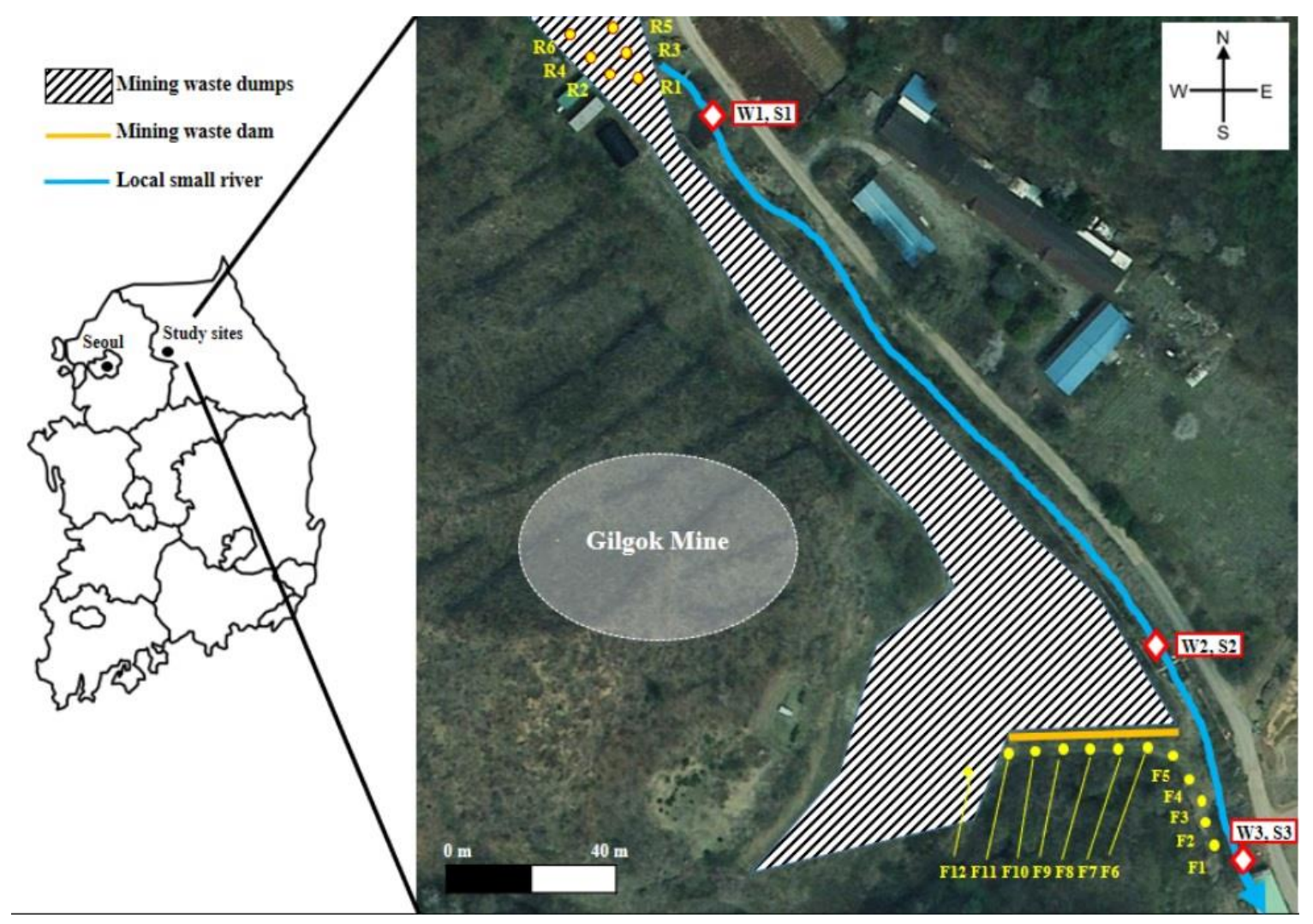

Figure 1. Study area closed to Gilgok abandoned mine and top soil (R and F), water (W), and sediment (S) sampling points.

The area of the top of the mine waste dump was selected as the rock (R) area, and the top soil within $15 \mathrm{~cm}$ depth was collected at six points. A dam was installed in 1999 to prevent a loss in mine waste. The lower part of the dam was selected as the forest $(\mathrm{F})$ area, and soil samples were collected at 12 points in contact with the stream at regular intervals. The total length of the concrete dam was $40 \mathrm{~m}$ and there were some holes in the walls for drainage during rainfall (Figure 2). Considering the slope and the direction of runoff during rainfall, the small stream (blue line in Figure 1) located east of the mine waste dump might be contaminated. Therefore, samples of water (W) and sediment (S) were also collected at 3 points where rainfall and lost soil could contaminate the stream (near $\mathrm{R}$ and $\mathrm{F}$ area). Altitude, R, W1, and S1 were considered to correspond to samples taken at the upstream region whereas F, W3, and S3 were considered to correspond to samples taken at the downstream region. All samples were collected in September 2019. 


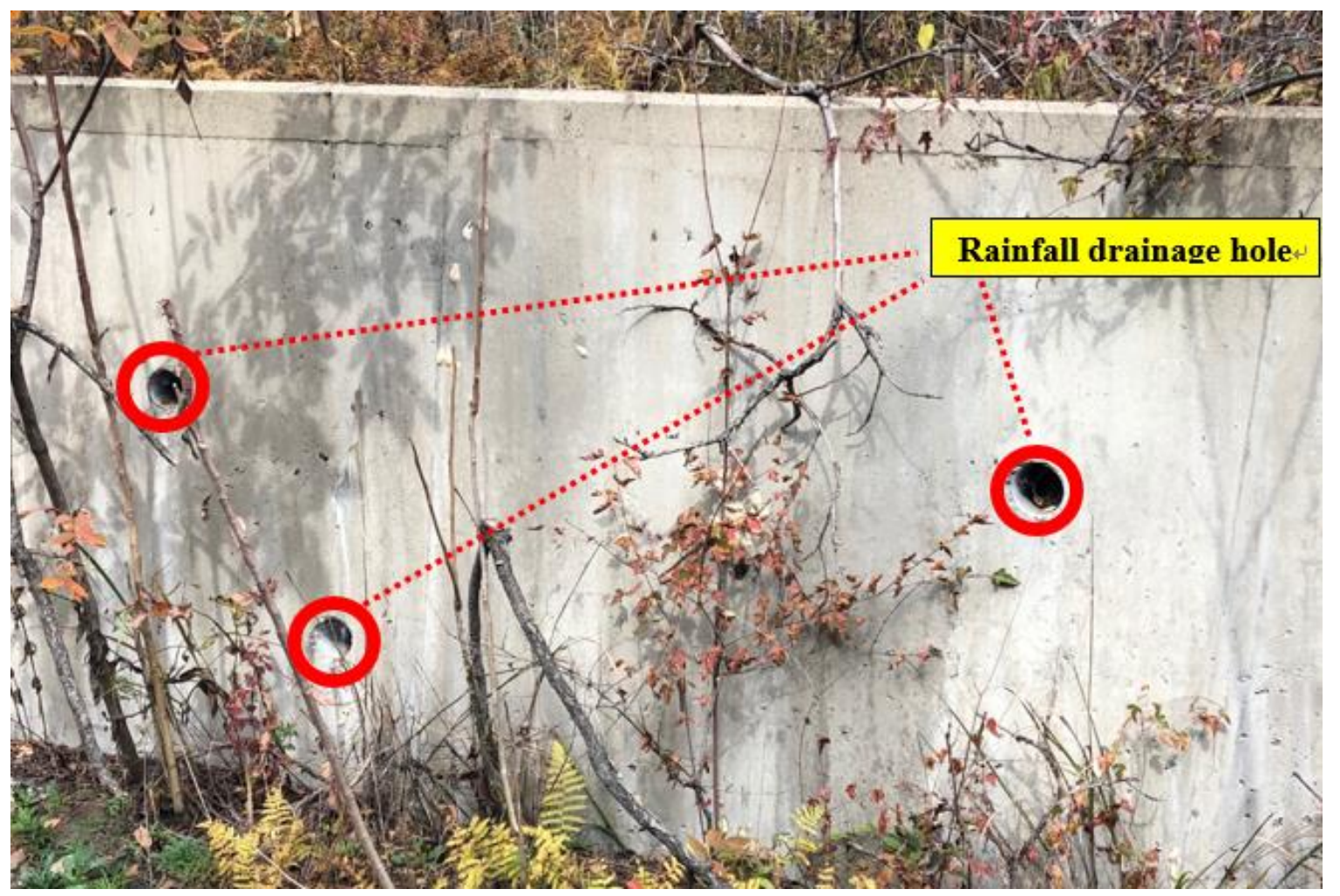

Figure 2. Rainfall drainage holes in the dam.

\subsection{Samples Analysis}

The top soil was collected at five points to make one composite soil sample for chemical analysis. The obtained soil sample was air-dried and passed through a $2 \mathrm{~mm}$ sieve. The $\mathrm{pH}$ of the soils was measured using a $\mathrm{pH}$ meter (Thermo Orion 920A, Thermo Fisher Scientific, Waltham, MA, USA) after mixing and stirring $5 \mathrm{~g}$ of soil and $25 \mathrm{~mL}$ of distilled water. The loss on ignition (LOI) was detected to determine the organic content at $400{ }^{\circ} \mathrm{C}$ over $16 \mathrm{~h}$ [26]. The particle size distribution was determined through the pipette method [27] after complete dispersion of soil particles using $5 \%$ sodium hexametaphosphoate solution and sampling aliquot solution according to the Stokes law. The concentration of the total As was determined by digesting soil samples with aqua regia, a mixture of $\mathrm{HNO}_{3} / \mathrm{HCl}(v: v=1: 3)$, in accordance with ISO 11466 [28]. As in sample solution was determined using an inductively coupled plasma optical emission spectrometer (ICP-OES, Agilent, Santa Clara, CA, USA). The accuracy of the analytical data with regards to the As was assessed using certified reference material (NIST 2711a, Montana II Soil, NIST, Gaithersburg, MD, USA). As soon as the water sample was collected and acidified in field, it was stored at $4{ }^{\circ} \mathrm{C}$ and brought to the laboratory. As concentration in the water sample was determined using inductively coupled plasma mass spectrometer (ICP-MS, Agilent, Santa Clara, CA, USA) after filtration through $0.45 \mathrm{um}$. The $\mathrm{pH}$, electrical conductivity (EC), dissolved oxygen (DO) and temperature were measured in situ with a portable multiparameter water quality meter (U-50 series, HORIBA, Kyoto, Japan). Sediment samples were also collected at the same points where the water sample were collected. Particle sizes, loss-on-ignition, and As concentration were analyzed by following the standard methods for examination of sediment by National Institute of Environmental Research (NIER) in Korea.

\subsection{Sequential and Single Extraction for Chemical Assessment}

The fraction of As was determined by sequential extraction, as described by Wenzel et al. [29].

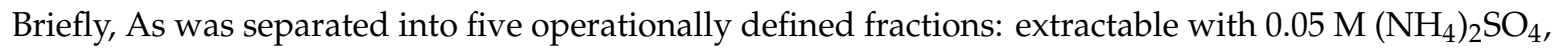
$20^{\circ} \mathrm{C} / 4 \mathrm{~h}$ (non-specifically sorbed, fr 1 ), extractable with $0.05 \mathrm{M} \mathrm{NH}_{4} \mathrm{H}_{2} \mathrm{PO}_{4}, 20^{\circ} \mathrm{C} / 16 \mathrm{~h}$ (specifically 
sorbed, fr2), extractable with $0.2 \mathrm{M} \mathrm{NH}_{4}$-oxalate buffer in the dark, $\mathrm{pH} 3.25,20^{\circ} \mathrm{C} / 4 \mathrm{~h}$ (amorphous and poorly crystalline hydrous metal oxides, fr3), extractable with $0.2 \mathrm{M} \mathrm{NH}_{4}$-oxalate buffer + ascorbic acid $\mathrm{pH} 3.25,96^{\circ} \mathrm{C} / 0.5 \mathrm{~h}$ (well-crystallized hydrous metal oxides, fr 4 ) and residual phases extracted (fr5). Among the fractions, the sum of $f r 1$ and $f r 2$ is considered to be the mobile fraction [30-32]. Sometimes, fr 3 fractions might be considered as a potentially bioavailable fractions, depending on the environmental conditions of the soil $[33,34]$.

In addition, several single extraction methods were also conducted to assess the mobility, bioavailability, human health risk, and leachability. For the assessment of the arsenic bioaccessibility in the soil, the acid-extractable fraction was measured. One gram of soil sample was agitated with 25 $\mathrm{mL}$ of $1 \mathrm{~N} \mathrm{HCl}$ for $4 \mathrm{~h}$ [35]. This method using $1 \mathrm{~N} \mathrm{HCl}$ is the same as the Standard Methods for the Examination of Environmental Soil Pollution used in Korea until 2010. Bioavailable As was examined using Mehlich-3 solution based on chelating agents [21,36,37]. Two grams of soil sample was agitated with $20 \mathrm{~mL}$ of mixed solution ( $\mathrm{pH}$ 2.3) containing $\mathrm{NH}_{4} \mathrm{~F}$, EDTA, $\mathrm{NH}_{4} \mathrm{NO}_{3}, \mathrm{CH}_{3} \mathrm{COOH}$ and nitric acid during $5 \mathrm{~min}$. The simple bioavailability extraction test (SBET), a simplified in vitro form, was used to determine the As bioaccessibility for human health [38] by simulating gastrointestinal conditions. Synthetic stomach fluid was prepared using glycine and adjusting to $\mathrm{pH} 1.5$ with conc. HCl. $100 \mathrm{~mL}$ of this solution was mixed with $1 \mathrm{~g}$ of soil for $1 \mathrm{~h}$ at $37^{\circ} \mathrm{C}$. The synthetic precipitation leaching procedure (SPLP) was conducted to evaluate the potential for leaching metals into the sub soil, groundwater, and river [39]. Twenty-five grams of soil sample was mixed with $500 \mathrm{~mL}$ of diluted $\mathrm{H}_{2} \mathrm{SO}_{4}+\mathrm{HNO}_{3}$ solution ( $\mathrm{pH} 4.20 \pm 0.05$ ) during $18 \mathrm{~h}$. All mixed solutions were filtrated by $0.45 \mathrm{um}$ filter paper and As in filtrate was measured using ICP-OES.

\subsection{Plant Cultivation Experiment for Biological Assessment}

Plant cultivation experiment using bok choy (Brassica campestris L. ssp. chinensis Jusl.) was conducted for the biological assessment of As contaminated soils. Twelve seeds were placed in $60 \times$ $15 \mathrm{~mm}$ petri dishes containing $5 \mathrm{~g}$ of quartz sand. After germination, the number of seedlings were unified to 10 and $35 \mathrm{~g}$ of field soil were added. For control treatment, peat moss was also used instead of soil. The moisture content was maintained at approximately $60 \%$ of the soil water holding capacity. The petri dishes were randomly placed in the growth chamber under controlled conditions and each sample was repeated in triplicate. The light conditions included $16 \mathrm{~h}$ of daylight and $8 \mathrm{~h}$ of darkness per day and the temperature was $24 \pm 2{ }^{\circ} \mathrm{C}$. Ten days after germination and exposure to soils, the seedlings were harvested and washed with de-ionized water and the root and shoot elongation was immediately measured using a desktop scanner (Epson Perfection V700 an image analyzer program (WinRhizo 5.0a, Reagent, Canada). Because all petri dishes contained 10 seedlings that were cultivated in each petri dish, the elongation results of bok choy are expressed in $\mathrm{cm} \mathrm{dish}^{-1}$.

\subsection{Data Analysis}

All measurements of analysis were taken in triplicate for each sample. A one-way analysis of variance (ANOVA) test was used to compare the means of different samples. When significant $p$-values $(p<0.05)$ were obtained, the differences between the means were evaluated by Tukey's test. Pearson's correlation coefficients were calculated among the As fraction by sequential extraction (\%), As bioavailability by several single extraction $\left(\mathrm{mg} \mathrm{kg}^{-1}\right)$. All data were analyzed using a statistical analysis system program (SAS 9.4, SAS Institute Inc., Cary, NC, USA).

\section{Results and Discussion}

\subsection{Soil, Water, and Sediment Characteristics}

Table 1 showed the basic properties of the soil. Because of the characteristics of parent rock (granite and/or granite gneiss) and climate (rapid leaching due to heavy rainfall in the summer) [11], the soil $\mathrm{pH}$ appeared to be slightly acidic. Owing to the long-term oxidation of the mine waste rock by 
a process of physicochemical weathering, the $\mathrm{pH}$ of the soil (R) located in the mine waste dump was observed to be the lowest; this was the biggest obstacle in the restoration of the abandoned mining area [40]. The content of organic matter was similar in general; this was however lower in the F soils overall. In the F area, the lower part of the mining waste dam seemed to be have been used as forest roads in the past and had a relatively low frequency of woody plants compared to the $\mathrm{R}$ area. The clay content was found to be distributed at a relatively similar level. In addition, characteristics of the nearby river water and sediments were also analyzed to identify the effect of mine waste rock piles as a non-point source. The $\mathrm{pH}$ of water and sediment were found to be slightly alkaline. Although it was about $250 \mathrm{~m}$ from $\mathrm{W} 1$ and $\mathrm{S} 1$ to $\mathrm{W} 3$ and S3, the $\mathrm{pH}$ tended to decrease as it went downstream. Though there was a low water level at the time of sampling, As was detected in the water from 5.9 to $7.5 \mu \mathrm{g}$ $\mathrm{L}^{-1}$. The As lost from large pile of mine waste was observed to have contaminated the sediments as well as rivers, evidenced by a value ranging from 47 to $175 \mathrm{mg} \mathrm{kg}^{-1}$.

Table 1. Basic properties of soil ( $R$ and F), water (W), and sediment (S).

\begin{tabular}{|c|c|c|c|c|c|c|}
\hline $\begin{array}{l}\text { Sample } \\
\text { Number }\end{array}$ & $\mathrm{pH}$ & $\begin{array}{c}\mathrm{LOI}^{\mathrm{a}} \\
(\%)\end{array}$ & $\begin{array}{l}\text { Sand } \\
(\%)\end{array}$ & $\begin{array}{l}\text { Silt } \\
(\%)\end{array}$ & $\begin{array}{l}\text { Clay } \\
(\%)\end{array}$ & $\begin{array}{l}\text { Total As Concentration } \\
\left(\mathrm{mg} \mathrm{kg}^{-1}\right)\end{array}$ \\
\hline R1 & 5.0 & 9 & 67 & 20 & 14 & 1449 \\
\hline R3 & 4.9 & 8 & 80 & 5 & 15 & 1673 \\
\hline $\mathrm{R} 4$ & 4.3 & 11 & 76 & 13 & 11 & 2239 \\
\hline R5 & 5.7 & 9 & 76 & 14 & 10 & 3944 \\
\hline $\mathrm{F} 1$ & 5.6 & 4.9 & 80 & 2 & 18 & 788 \\
\hline $\mathrm{F} 2$ & 5.8 & 4.1 & 79 & 6 & 15 & 1716 \\
\hline F3 & 6.2 & 5.7 & 75 & 9 & 16 & 3418 \\
\hline $\mathrm{F} 4$ & 6.2 & 5.7 & 73 & 13 & 14 & 4153 \\
\hline F5 & 6.3 & 5.0 & 75 & 9 & 16 & 4614 \\
\hline F6 & 6.6 & 7.7 & 69 & 16 & 15 & 5899 \\
\hline F10 & 7.2 & 4.7 & 59 & 26 & 15 & 7960 \\
\hline F11 & 7.6 & 4.5 & 65 & 21 & 15 & 7871 \\
\hline F12 & 3.8 & 4.0 & 76 & 1 & 23 & 9079 \\
\hline S1 & 7.9 & 3.7 & 88 & 3 & 9 & 143 \\
\hline $\mathrm{S} 2$ & 7.7 & 1.6 & 87 & 4 & 9 & 175 \\
\hline S3 & 7.6 & 4.2 & 89 & 2 & 9 & 47 \\
\hline $\begin{array}{l}\text { Sample } \\
\text { Number }\end{array}$ & $\mathrm{pH}$ & $\begin{array}{c}\mathrm{EC}^{\mathrm{b}} \\
\left(\text { us cm }^{-1}\right)\end{array}$ & $\begin{array}{c}\mathrm{DO}^{\mathrm{c}} \\
\left(\mathrm{mg} \mathrm{L}^{-1}\right)\end{array}$ & \multicolumn{2}{|c|}{$\begin{array}{c}\text { Temperature } \\
\left({ }^{\circ} \mathrm{C}\right)\end{array}$} & $\begin{array}{l}\text { As Concentration } \\
\left(\mathrm{ug} \mathrm{L}^{-1}\right)\end{array}$ \\
\hline W1 & 8.2 & 92 & 13.5 & \multicolumn{2}{|c|}{16.0} & 5.9 \\
\hline W2 & 6.9 & 111 & 9.4 & \multicolumn{2}{|c|}{16.5} & 7.5 \\
\hline
\end{tabular}

Although the mine waste dump was located in the $\mathrm{R}$ area, the forest soil in the $\mathrm{F}$ area below the dam was also contaminated with a high concentration of As. Of the six sampling points, the concentration of As was found to be the highest in the $\mathrm{R}$ area $\left(4142 \mathrm{mg} \mathrm{kg}^{-1}\right)$. In addition, nine of the twelve soil samples (F4-F12) in the F area had a contamination level of As above $4142 \mathrm{mg} \mathrm{kg}^{-1}$. Considering the site's topography and the decreases in As concentration along the slope, As was discharged as rain fell on the mine waste pile, $R$ area. In addition, the effluent containing As was either flowing into $\mathrm{W} 1$ along the surface water or entering the $\mathrm{F}$ area through the holes (for drainage) of the dam (Figure 2). Several studies have reported that such huge amounts mine waste and rainfall have additionally contaminated the surrounding environments $[5,41]$ and, in particular, the presence of large cracks increases the leachability and mobility of trace elements and the process of weathering [42]. 


\subsection{As Fraction in Soils Near the Mine Waste Duump and Dam}

It is unusual for the highest concentration of As $\left(9079 \mathrm{mg} \mathrm{kg}^{-1}\right)$ to have been observed at the highest altitude (F12) in the F area, close to the dam, rather than in the mine waste (R area), and that the concentration of As decreased gradually as it descended to point W3, where the rainfall runoff flowed into the river. Benvenuti et al. [6] reported that the degree of contamination decreased while moving downstream, due to the metal adsorption and precipitation of the solid phases rather than the dilution effects. Therefore, to confirm the behavior and fraction of As in the soil, a method of sequential extraction was used (Figure 3). For clarity, As was adsorbed by well-crystallized hydrous metal oxides ( $f r 4$ ) and the residual As ( $f r 5)$ were combined and presented in a group as ' $f r 4+f r 5$ '. A noticeable result was demonstrated between the soils of the R area and F area. First, exchangeable As ( $f r 1$ ), which is very weakly bound to the soil and can be easily replaced or lost, was detected in both soils; however, its level was very low compared to the total concentration $(0.01 \%-0.03 \%$ and $0.07 \%-0.78 \%$ for $\mathrm{R}$ soils, and F soils, respectively). Specifically, the adsorbed fraction of $f r 2$ was $2 \%-5 \%$ in the R soil; this was also very low compared to the total amount, and that of $\mathrm{F}$ soil (8-14\%), which was three times as much as that of $\mathrm{R}$ soil. The percentage of $f r 1$ and fr 2 relative to the total amount could be seen as a mobility factor (MF) [23], and it can be understood that the movement of pollutants was relatively easy. The largest difference between $\mathrm{R}$ and $\mathrm{F}$ soil is the fraction that is bound to amorphous metal oxides ( $f r 3$ ). In R soil, As binding with $f r 3$ was $9 \%-37 \%$, whereas in F soil, more than half $50 \%-80 \%$ of As was in the $f r 3$ fraction. Although more tightly bound to soil than $f r 1$ and $f r 2$, it is also seen as an MF that combines fr 1, fr 2, and fr 3, considering the mobility potential [34]. On the contrary, the sum of the fractions fr 4 and fr 5, which is relatively stable and difficult to lose in a short time, was $64 \%-88 \%$ and $10 \%-38 \%$ in the R soil and F soil, respectively. This indicated that As in the R soil was more strongly bound to the soil. The result of the analysis of the bound form of As through sequential extraction provided evidence supporting the assumption that As had been lost in the $\mathrm{R}$ area, whereas it was adsorbed and contaminated at the lower point, the F area. In 2019, 20 years after the dam was installed, the results of analysis showed that the MF ( fr $1+f r 2+f r 3)$ of As in the R soil was low considering the mobility potential [34]. This was because the process of natural weathering had removed the fraction that was likely desorbed and dissociated from the soil. On the contrary, MF was relatively high in the F soil. The fr 3 , a fraction of which comprises amorphous metal hydroxides (one of the sites where As is well adsorbed) was the highest [43,44]. As is well known to be easily and quickly adsorbed and combines with hydroxides and oxides owing to the presence of metals (especially iron (Fe)) in the soil environment $[17,23]$. As a result, mobile As was observed to have been continuously lost from the top of the $\mathrm{R}$ soil down to the bottom for a very long time before the dam was installed, resulting in a very low fr $1+f r 2+f r 3$ fraction in the R soil. Of the As fractions, only fractions that were strongly bound to the soil ( fr $4+f r 5$ ) remained at this point. On the contrary, the F soil could easily lose As again via transport to the river (W3) and sediment (S3). Meanwhile, some of the As could easily bind to Fe oxides in the soil and remain in the form of inner sphere complex [45], ultimately resulting in the highest fr 3 fraction.

On the flip side, As in the outflow of the mine waste dump ( $\mathrm{R}$ area) could be removed through the forest soil (F area), called the buffer zone, before being introduced into the river (W3), thereby reducing the amount of As being loaded into the stream. During a period of heavy rainfall in the summer, there may not be enough time to check the F soil for As adsorption, or the F soil may have reached its maximum As adsorption capacity, thereby resulting in a loss of As, and its detection in the sediment (S3). In summary, even if the dam was constructed in the abandoned mining areas to prevent a loss in mine waste, it was confirmed that the nearby forest soil, water, and sediments were contaminated. Therefore, the method of sequential extraction could be useful in estimating the behavior of As over time. 


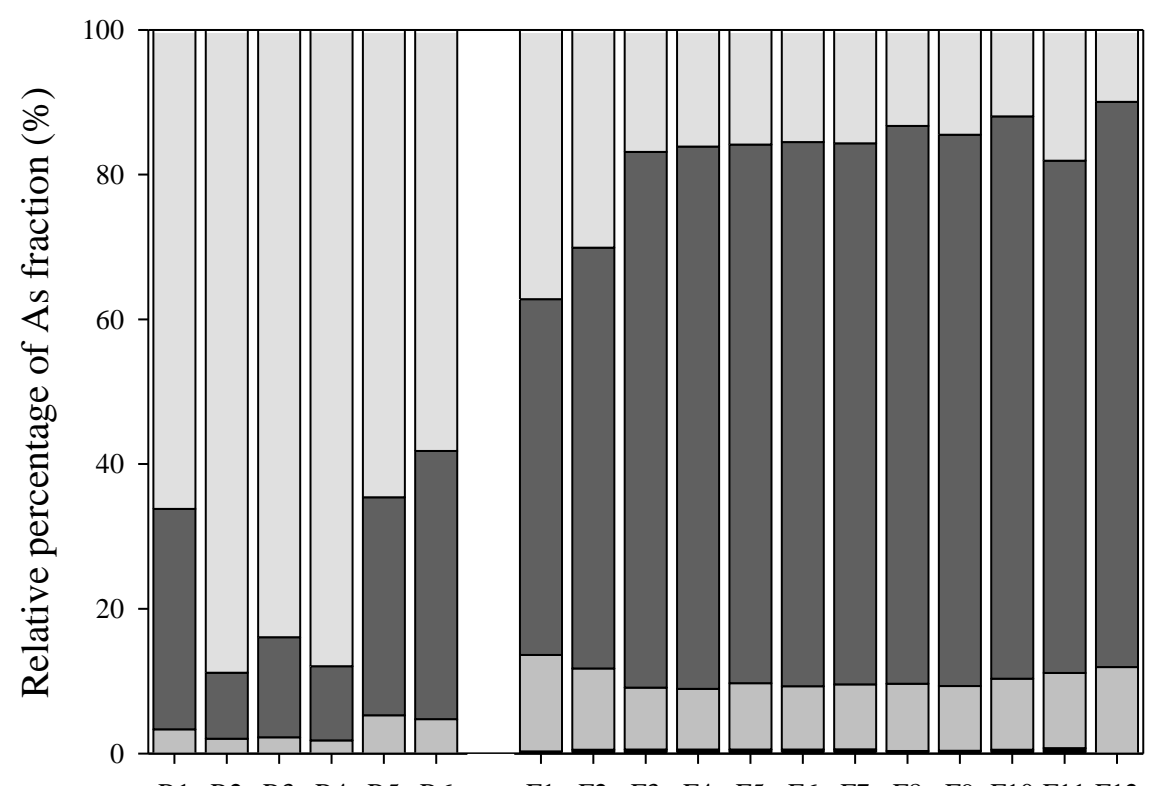

Soil samples

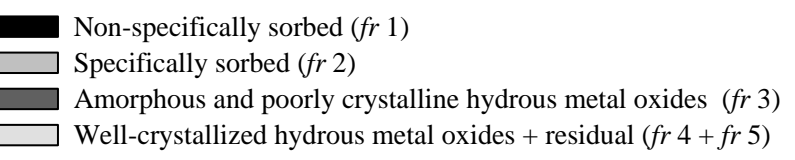

Figure 3. Results of Wenzel's sequential extraction for mine waste (R) and forest (F) area soils.

\subsection{Chemical Assessment for As Mobility and Bioavailability}

Based on the total concentration of As and the results of sequential extraction analysis, four types of single extraction were performed to test the bioavailability and potential mobility of As in the soil (Table 2). Of the four types of single extraction, the highest absolute leaching amount $\left(\mathrm{mg} \mathrm{kg}^{-1}\right) \mathrm{was}$ observed in the method where an acid solution of $1 \mathrm{~N} \mathrm{HCl}$ was used. This solution has been known to destroy the physical structure and chemical binding of the soil fairly well.

Table 2. As concentration ( $\mathrm{mg} \mathrm{kg}^{-1}$ ) extracted by single extraction methods *.

\begin{tabular}{|c|c|c|c|c|}
\hline Sample Number & Mehlich-3 & $1 \mathrm{~N} \mathrm{HCl}$ & SBET $^{a}$ & SPLP $^{b}$ \\
\hline R1 & $6 c$ & $132 \mathrm{~b}$ & $7 \mathrm{c}$ & $0.9 \mathrm{bc}$ \\
\hline $\mathrm{R} 2$ & $2 \mathrm{~d}$ & $56 \mathrm{~b}$ & $10 \mathrm{bc}$ & $1.1 \mathrm{bc}$ \\
\hline R3 & $2 \mathrm{~d}$ & $81 \mathrm{~b}$ & $2 c$ & $0.6 \mathrm{c}$ \\
\hline $\mathrm{R} 4$ & $2 d$ & $49 \mathrm{~b}$ & $4 \mathrm{c}$ & $2.0 \mathrm{a}$ \\
\hline $\mathrm{R} 5$ & $32 \mathrm{a}$ & $657 \mathrm{a}$ & $26 \mathrm{ab}$ & $1.7 \mathrm{ab}$ \\
\hline R6 & $27 \mathrm{~b}$ & $764 \mathrm{a}$ & $38 \mathrm{a}$ & $1.6 \mathrm{ab}$ \\
\hline $\mathrm{F} 1$ & $24 \mathrm{~h}$ & $251 \mathrm{e}$ & $30 \mathrm{~h}$ & $1.7 \mathrm{~g}$ \\
\hline $\mathrm{F} 2$ & $103 \mathrm{~g}$ & $64 \mathrm{e}$ & $106 \mathrm{~h}$ & $9.7 \mathrm{f}$ \\
\hline F3 & $214 \mathrm{f}$ & $1302 \mathrm{~d}$ & $236 \mathrm{~g}$ & $26.6 \mathrm{e}$ \\
\hline $\mathrm{F} 4$ & $277 \mathrm{e}$ & $1637 \mathrm{~d}$ & $383 \mathrm{f}$ & $36.3 \mathrm{~d}$ \\
\hline F5 & $289 \mathrm{e}$ & $1719 \mathrm{~d}$ & $352 \mathrm{f}$ & $40.1 \mathrm{~cd}$ \\
\hline F6 & $352 \mathrm{~cd}$ & $2870 \mathrm{c}$ & $500 \mathrm{de}$ & $58.5 \mathrm{~b}$ \\
\hline F7 & $358 \mathrm{~cd}$ & $2664 \mathrm{c}$ & $534 \mathrm{de}$ & $60.7 \mathrm{~b}$ \\
\hline F8 & $413 \mathrm{~b}$ & $2849 \mathrm{c}$ & $474 \mathrm{e}$ & $40.8 \mathrm{~cd}$ \\
\hline F9 & $378 \mathrm{bc}$ & $3053 c$ & $556 \mathrm{~cd}$ & $44.2 \mathrm{c}$ \\
\hline F10 & $523 \mathrm{a}$ & $3527 b$ & 1376 a & $69.1 \mathrm{a}$ \\
\hline F11 & $382 \mathrm{bc}$ & $3687 \mathrm{~b}$ & $962 b$ & $62.2 \mathrm{~b}$ \\
\hline F12 & $329 \mathrm{~d}$ & 4630 a & $612 c$ & $2.0 \mathrm{~g}$ \\
\hline
\end{tabular}

* Different letter indicates significant differences at the $5 \%$ level by Tukey's test. ${ }^{\text {a }}$ Simple bioavailability extraction test; ${ }^{b}$ synthetic precipitation leaching procedure. 
Next, the SBET, which assesses the risk to human health by simulating the digestive fluid was conducted, after which a large amount of As was extracted. As was extracted in the order of chelate-based Mehlich-3 solution and SPLP methodology; this represents the potential mobility by simulating the amount leached using synthetic rain. For both $\mathrm{R}$ and $\mathrm{F}$ soils, the bioavailability and mobility of As were found to rise with an increase in the total content of As in the soil. A correlation analysis was performed to confirm the relationship among the results of chemical assessments (Table 3 ).

Table 3. Correlation coefficients $(r)$ among the results of As analysis.

\begin{tabular}{ccccc}
\hline R Soil & Mehlich-3 & 1N HCl & SBET $^{\mathbf{a}}$ & SPLP $^{\mathbf{b}}$ \\
\hline Total As & $0.940^{*}$ & $0.957^{*}$ & $0.922^{*}$ & 0.630 \\
fr 1 & 0.063 & -0.083 & -0.100 & -0.372 \\
fr 2 & $0.971^{*}$ & $0.940^{*}$ & $0.859^{*}$ & 0.288 \\
fr 3 & $0.826^{*}$ & $0.841^{*}$ & 0.783 & 0.137 \\
\hline F Soil & Mehlich-3 & $\mathbf{1 N ~ H C l}$ & SBET & SPLP \\
\hline Total As & $0.890^{* *}$ & $0.980^{* *}$ & $0.786^{*}$ & 0.523 \\
fr 1 & 0.090 & -0.212 & 0.183 & $0.597^{*}$ \\
fr 2 & -0.562 & -0.238 & -0.181 & -0.435 \\
fr 3 & $0.687^{*}$ & $0.684^{*}$ & $0.632^{*}$ & 0.395 \\
\hline
\end{tabular}

*,** Represent significant at $p<0.05$ and $p<0.001$, respectively, according to Pearson's correlation analysis. ${ }^{\text {a simple }}$ bioavailability extraction test; ${ }^{\mathrm{b}}$ synthetic precipitation leaching procedure.

SPLP has been widely applied for assessing the risk of As mobility in abandoned mining areas [46-48]. In both $\mathrm{R}$ and $\mathrm{F}$ soils, the total As content was not significantly correlated $(p>0.05)$ only with the SPLP method, where a relatively mild solution was used. Unlike R soil that has a high fraction of fr 4 and fr 5, which are difficult to extract, significant correlation was found in fr 1, which easily dissociated from the F soil due to a high MF [23]. In general, soils contaminated with As from geogenic sources such as mine waste showed lower bioavailability of As than did anthropogenic contaminated soil (from sources such as coal combustion, pesticides, and wood preservatives) [48]. Thus, compared to geogenically contaminated R soil, higher bioavailability and potential mobility of As was found in secondary contaminated F soil. In view of the above result, the secondary contaminated soil as a sink could also serve as a source of contamination of the downstream area by As re-dissolution and leaching (by rainfall) from the $\mathrm{F}$ soil. Although the range of total As concentration in the $\mathrm{F}$ soil was very wide, from 788 to $9079 \mathrm{mg} \mathrm{kg}^{-1}$, Mehlich-3, $1 \mathrm{~N} \mathrm{HCl}$, and SBET extraction results showed a significant correlation with the total concentration and the $f r 3$ of As $(p<0.05)$. In the R soil, the result of $f r 2$ and $f r$ 3 could explain the relationship with Mehlihch-3, $1 \mathrm{~N} \mathrm{HCl}$, and SBET, although the fr 2 of $\mathrm{F}$ soil had no correlation with single extraction methods. In the case of F soil, the $f r 3$ ratio was very high, and a significant portion of the fr 3 leached into the three extraction solutions; this significantly influenced the statistical results. In the case of the R soil, owing to the high ratio of $f r 4$ and $f r 5$, the inference from the result was that the extraction solution evenly leached at $f r 2$ and $f r 3$, respectively. Juhasz et al. [49] reported that SBET fraction was also associated with $f r$ 1, fr 2, and $f r 3$ in As spiked Red Ferrosol soil. Fayiga and Ma [50] reported that Mehlich-3 extractable As was associated with Fe/Al fraction and the uptake of As by ferns. Kim et al. [51] also reported that $1 \mathrm{~N} \mathrm{HCl}$ could dissolve 5.4 to $41.9 \%$ of the total amount of As in the soil and $1 \mathrm{~N} \mathrm{HCl}$ extractable As was well correlated with the fr 3 of paddy soil in Korea. In summary, these single extraction methods could be utilized for the assessment of As bioavailability in secondary contaminated soil with high MF, such as F soil in this study.

\subsection{Plant Cultivation Experiment for Biological Assessment}

On the basis of the chemical assessment results, a plant cultivation experiment was also conducted to evaluate the relationship among the above results (Figure 4). Considering practical applicability in the field, bok choy, which has been used for the trace elements phytotoxicity test with a balance between sensitivity and extreme insensitivity was selected after germination and grown only for 
10 days (early growth stage of seedlings) in order to identify the toxic effect of As rather than soil properties $[5,21,23]$.

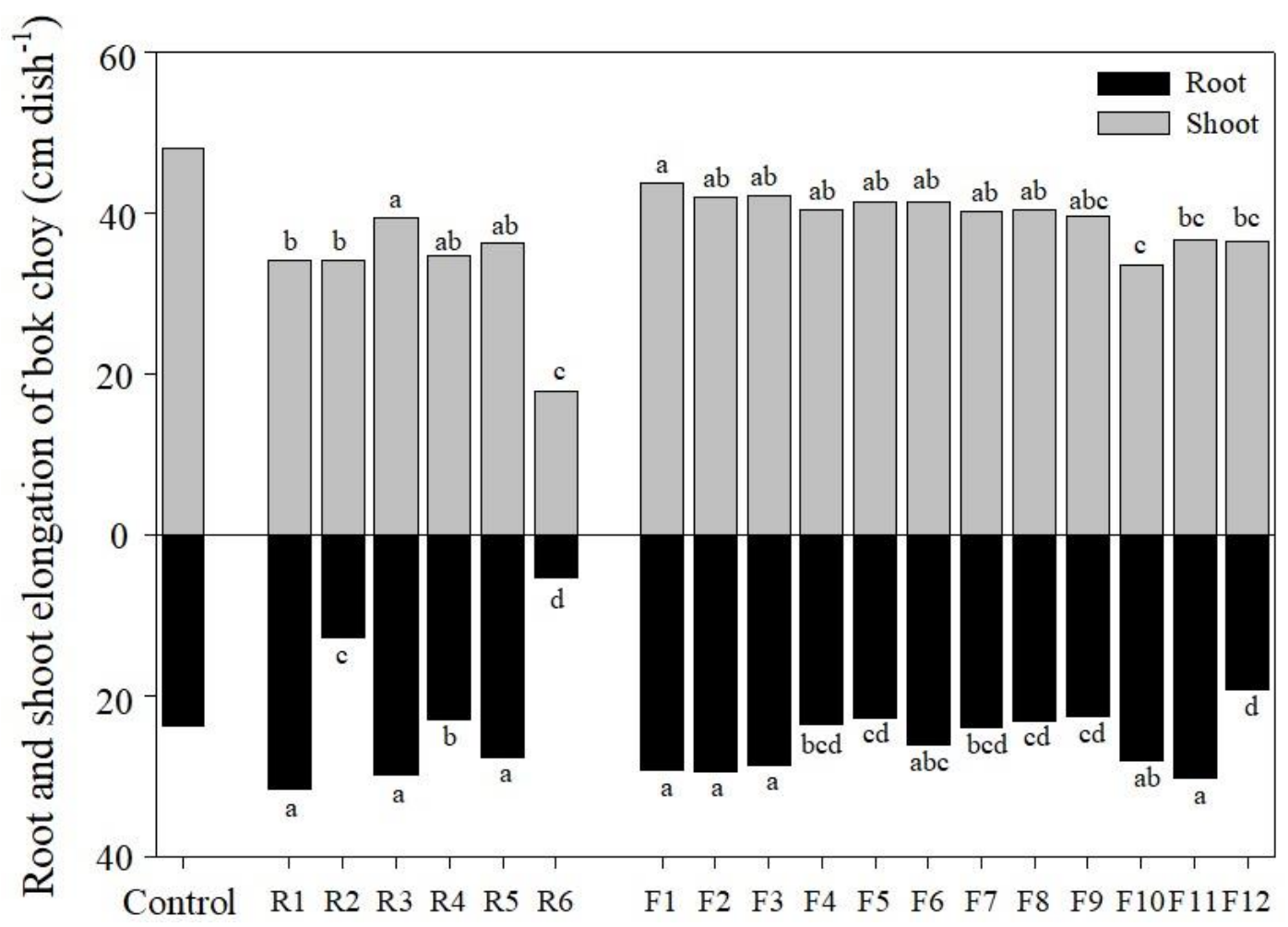

Figure 4. Results of 10-day cultivation test of control, rock (R) area, and forest (F) area soils using bok choy. Different letter indicates significant differences at the $5 \%$ level by Tukey's test.

Root and shoot elongation of a 10-days old seedling of bok choy cultivated in peat moss for control were 23.7 and $48.0 \mathrm{~cm} \mathrm{dish}^{-1}$, respectively. In the R soil, bok choy in R2, R4, and R6 were significantly inhibited $(p<0.05)$ in root growth compared to R1, R3, and R5. The main factors responsible for the result obtained seem to be the $\mathrm{pH}$ and As content. The $\mathrm{pH}$ of $\mathrm{R} 2, \mathrm{R} 4$, and $\mathrm{R} 6$ soil were too low for the normal growth of the plants. The growth of bok choy was significantly inhibited in R6 due to a high acidic condition, high As total concentration (4142 $\mathrm{mg} \mathrm{kg}^{-1}$ ) and a high portion of MF (fr $\left.1+f r 2+f r 3\right)$ compared to other R soils. Particularly, below a pH of 5.5, the growth of plants is known to be adversely affected by sulfide oxidation and exchangeable aluminum [52]. In both $\mathrm{R}$ and F soils, since the shoot of the plant is indirectly affected by the soil environments unlike the roots, the differences in shoot elongation by soil properties and As concentration is relatively small. Contrary to the R soil, there was no noticeable growth inhibition in the root for F soils (soil pH; 5.6 to 7.6). However, in F12 soil that had a very low $\mathrm{pH}$ and the highest concentration $\left(9079 \mathrm{mg} \mathrm{kg}^{-1}\right)$ of As, the inhibition of root elongation was observed $(p<0.05)$. F12 had a high total concentration of As, however, when compared among single extraction methods, the absolute amount of As extract was relatively low in F12 due to a low $\mathrm{pH}$ of 3.8. This was because the mobility and availability of As in oxidized soil (unlike paddy soil and sediments) increased with increasing $\mathrm{pH}$ of the soil, due to the adsorption/desorption characteristics with metal oxides [53]. Apart from the $\mathrm{pH}$, the reduction potential, DOC, microbial population, and various types of adsorption sites have a great influence on the behavior of As [19,54]. Nevertheless, soil $\mathrm{pH}$ was observed to have a significant impact on the rootage, which is a very important factor in the growth of young plants. If the possibility of phytoremediation based on the results of the cultivation experiment is open, it is necessary to use iron-based stabilizers (zero valent iron, steel slang, acid mine drainage sludge, etc.) and organic materials, such as biochar, to possibly adjust the $\mathrm{pH}$ and supply adsorption sites before the introduction of plants via transplanting or seed spreading $[3,19,20,23,24]$. 


\section{Conclusions}

This research was conducted to monitor the effect of the dam installed in a small mountain village for preventing the loss of mine waste containing high concentrations of As on the surrounding environments and to evaluate their impacts using various methods of assessment. Just like the waste rock soil, the forest soil under the dam was also contaminated with As; this could be considered as being secondarily contaminated on the basis of the following evidence: (1) a gradual and consistent decrease in the concentration of As in forest soils away from the mine waste dam, (2) well crystallized hydrous metal oxides and residual phases were the main fractions of mine waste soil, however, MF including non-specifically sorbed, specifically sorbed, amorphous and poorly crystalline hydrous metal oxides were the main fractions in forest soils, and (3) sediment deposits from nearby rivers were also contaminated with As. Therefore, sequential and single extraction could explain the mobility and bioavailability of As in abandoned mining areas. In addition, the SPLP analysis showed that As could be re-dissolved from secondary contaminated forest soil and spread to nearby environments. From these results, we could confirm the necessity and importance of post-management after the reclamation of an abandoned mining area through various methods of analyzing As.

Author Contributions: Conceptualization, M.-S.K.; methodology, S.-H.L.; writing—original draft preparation, M.-S.K.; writing-review and editing, J.-G.K. and S.-H.L. All authors have read and agreed to the published version of the manuscript.

Funding: This research was funded by Basic Science Research Program through the National Research Foundation of Korea (NRF) [2016R1D1A1B03932877] and partly supported by Korea University.

Conflicts of Interest: The authors declare no conflict of interest. The funders had no role in the design of the study; in the collection, analyses, or interpretation of data; in the writing of the manuscript, or in the decision to publish the results.

\section{References}

1. KMoTIE. Annual Report of Environmental Status in Mining Areas; Ministry of Trade, Industry, and Energy of the Korea: Sejong, Korea, 2010.

2. Kim, M.S.; Park, M.J.; Yang, J.H.; Lee, S.H. Human health risk assessment for toxic trace elements in the Yaro mine and reclamation options. Int. J. Environ. Res. Public Health 2019, 16, 5077. [CrossRef] [PubMed]

3. Koo, N.; Lee, S.H.; Kim, J.G. Arsenic mobility in the amended mine tailings and its impact on soil enzyme activity. Environ. Geochem. Health 2012, 34, 337-348. [CrossRef] [PubMed]

4. Abdul, K.S.M.; Jayasinghe, S.S.; Chandana, E.P.S.; Jayasumana, C.; De Silva, P.M.C.S. Arsenic and human health effects: A review. Environ. Toxicol. Pharmacol. 2015, 40, 828-846. [CrossRef] [PubMed]

5. Kim, M.S.; Min, H.G.; Kim, J.G.; Lee, S.R. Estimating arsenic mobility and phytotoxicity using two different phosphorous fertilizer release rates in soil. Agronomy 2019, 9, 111. [CrossRef]

6. Benvenuti, M.; Mascaro, I.; Corsini, F.; Lattanzi, P.; Parrini, P.; Tanelli, G. Mine waste dumps and heavy metal pollution in abandoned mining district of Boccheggiano (Southern Tuscany, Italy). Environ. Geol. 1997, 30, 238-243. [CrossRef]

7. Choong, T.S.Y.; Chuah, T.G.; Robiah, Y.; Koay, F.L.G.; Azni, I. Arsenic toxicity, health hazards and removal techniques from water: An overview. Desalination 2007, 217, 139-166. [CrossRef]

8. Lottermoser, B. Mine Waste: Characterization, Treatment and Environmental Impacts; Springer: Berlin/Heidelberg, Germany, 2007; ISBN 3-540-48629-1.

9. Favas, P.J.C.; Martino, L.E.; Prasad, M.N.V. Abandoned mine land reclamation-Challenges and opportunities (Holistic Approach). In Bio-Geotechnologies for Mine Site Rehabilitation; Prasad, M.N.V., Favas, P.J.C., Maiti, S.K., Eds.; Elsevier: Amsterdam, The Netherlands, 2018; pp. 3-31. ISBN 9780128129869.

10. Kim, H.J.; Park, B.K.; Kong, S.H.; Lee, J.Y.; Ok, Y.S.; Jun, S.H. Fraction and geoaccumulation assessment index of heavy metals in abandoned mines wastes. J. Soil Groundw. Environ. 2005, 10, 75-80.

11. Kim, M.S.; Kim, Y.S.; Min, H.G.; Kim, J.G.; Koo, N. Pine forest soil characteristics and major soil impact factors for natural regeneration. Korean J. Soil Sci. Fertil. 2017, 50, 179-186. [CrossRef]

12. Kossoff, D.; Hudson-Edwards, K.A.; Dubbin, W.E.; Alfredsson, M. Major and trace metal mobility during weathering of mine tailings: Implications for floodplain soils. Appl. Geochem. 2012, 27, 562-576. [CrossRef] 
13. Gao, Y.; Bradshaw, A.D. The containment of toxic wastes: II. Metal movement inn leachate and drainage at Parc leadn/zinc mine, North Wales. Environ. Pollut. 1995, 90, 379-382. [CrossRef]

14. Fosso-Kankeu, E.; Barlow, B.; Lemmer, N.; Waanders, F. Geochemical speciation of metal ions in the leachate of tailings treated with synthetic rain water. In Proceedings of the International Conference on Advances in Science, Engineering, Technology \& Waste Management, Parys, South Africa, 27-28 November 2017; pp. 19-23.

15. Kim, S.; Devineni, N.; Lall, U.; Kim, H.S. Sustainable development of water resources: Spatio-temporal analysis of water stress in South Korea. Sustainability 2018, 10, 3795. [CrossRef]

16. Kang, G.C.; Ahn, N.K.; Oh, J.I.; Kim, T.H. Stability investigation of the large size heap of coal associated wastes. J. Eng. Geol. 2005, 15, 133-144.

17. Mine Reclamation Corporation (MIRECO). Safety Evaluation and Development of Maintenance Technique for Tailing Dam; Technical Report (Research); MIRECO: Wonju, Korea, 2016; pp. 1-172.

18. Masscheleyn, P.H.; Delaune, R.D.; Patrick, W.H. Effect of redox potential and pH on arsenic speciation and solubility in contaminated soil. Environ. Sci. Technol. 1991, 25, 1414-1419. [CrossRef]

19. Sadiq, M. Arsenic chemistry in soils: An overview of thermodynamic predictions and field observations. Water Air Soil Pollut. 1997, 93, 117-136. [CrossRef]

20. Koo, N.; Kim, M.S.; Hyun, S.H.; Kim, J.G. Effects of the incorporation of phosphorus and iron into arsenic-spiked artificial soils on root growth of lettuce using response surface methodology. Commun. Soil Sci. Plant Anal. 2013, 44, 1259-1271. [CrossRef]

21. Lee, S.H.; Kim, E.Y.; Park, H.; Yun, J.; Kim, J.G. In situ stabilization of arsenic and metal-contaminated agricultural soil using industrial by-products. Geoderma 2011, 161, 1-7. [CrossRef]

22. Sadiq, M.; Zaidi, T.H.; Mian, A.A. Environmental behavior of arsenic in soils: Theoretical. Water Air Soil Pollut. 1983, 20, 369-377. [CrossRef]

23. Kim, M.S.; Min, H.G.; Lee, S.H.; Kim, J.G. The effects of various amendments on trace element stabilization in acidic, neutral and alkali soil with similar pollution index. PLoS ONE 2016, 11, e0166335. [CrossRef]

24. Kim, M.S.; Min, H.G.; Koo, N.; Park, J.S.; Lee, S.H.; Bak, G.I.; Kim, J.G. The effectiveness of spent coffee grounds and its biochar on the amelioration of heavy metals-contaminated water and soil using chemical and biological assessment. J. Environ. Manag. 2014, 146, 130. [CrossRef]

25. Bowell, R.J. Sorption of arsenic by iron oxides and oxyhydroxides in soils. Appl. Geochem. 1994, 126, $157-167$. [CrossRef]

26. Nelson, D.W.; Sommers, L.E. Total carbon, organic carbon, and organic matter. In Methods of Soil Analysis Part 3-Chemical Methods; Sparks, D.L., Ed.; SSSA: Madison, WI, USA, 1996; pp. 961-1010. ISBN 9780891188254.

27. NIAST. Method of SOIL and Plant Analysis; National Institute of Agricultural Science and Technology, Rural Development Administration: Suwon, Korea, 2000.

28. ISO. Soil Quality-Extraction of Trace Elements Soluble in Aqua Regia; ISO 11466; International Organization of Standardization: Geneva, Switzerland, 1995.

29. Wenzel, W.W.; Kirchbaumer, N.; Prohaska, T.; Stingeder, G.; Lombi, E.; Adriano, D.C. Arsenic fractionation in soils using an improved sequential extraction procedure. Anal. Chim. Acta 2001, 436, 309-323. [CrossRef]

30. Narwal, R.P.; Singh, B.R.; Salbu, B. Association of Cd, Zn, Cu, and Ni with components in naturally heavy metal rich soils studied by parallel and sequential extractions. Commun. Soil Sci. Plant Anal. 1999, 30, 1209-1230. [CrossRef]

31. Lee, S.H.; Ji, W.H.; Lee, W.S.; Koo, N.; Koh, I.H.; Kim, M.S.; Park, J.S. Influence of amendments and aided phytostabilization on metal availability and mobility in $\mathrm{Pb} / \mathrm{Zn}$ mine tailings. J. Environ. Manag. 2014, 139, 15-21. [CrossRef] [PubMed]

32. Sofianska, E.; Michailidis, K. Chemical assessment and fractionation of some heavy metals and arsenic in agricultural soils of the mining affected Drama plain, Macedonia, northern Greece. Environ. Monit. Assess. 2015, 101. [CrossRef]

33. Hsu, W.M.; His, H.C.; Huang, Y.T.; Liao, C.S.; Hseu, Z.Y. Partitioning of arsenic in soil-crop systems irrigated using groundwater: A case study of rice paddy soils in southwestern Taiwan. Chemosphere 2012, 86, 606-613. [CrossRef]

34. Liu, C.; Yu, H.Y.; Liu, C.; Li, F.; Xu, X.; Wang, Q. Arsenic availability in rice from a mining area: Is amorphous iron oxide bound arsenic a source or sink? Environ. Pollut. 2015, 199, 95-101. [CrossRef] 
35. Kashem, M.A.; Singh, B.R.; Kondo, T.; Huq, S.M.I.; Kawai, S. Comparison of extractability of Cd, Cu, Pb and Zn with sequential extraction in contaminated and non-contaminated soils. Int. J. Environ. Sci. Technol. 2007, 4, 169-176. [CrossRef]

36. Mehlich, A. Mehlich 3 soil test extractant: A modification of Mehlich 2 extractant. Commun. Soil Sci. Plant Anal. 1984, 14, 1409-1416. [CrossRef]

37. Lopes, C.; Herva, M.; Franco-Uría, A.; Roca, E. Multicorrelation models and uptake factors to estimate extractable metal concentrations from soil and metal in plants in pasturelands fertilized with manure. Environ. Pollut. 2012, 166, 17-22. [CrossRef]

38. Kim, J.Y.; Kim, K.W.; Lee, J.U.; Lee, J.S.; Cook, J. Assessment of as and heavy metal contamination in the vicinity of duckum Au-Ag mine, Korea. Environ. Geochem. Health 2002, 24, 213-225. [CrossRef]

39. USEPA. Synthetic Precipitation Leaching Procedure (SPLP); Method 1312; EPA: Washington, DC, USA, 1994.

40. Shu, W.S.; Ye, Z.H.; Lan, C.Y.; Zhang, Z.Q.; Wong, M.H. Acidification of lead/zinc mine tailings and its effect on heavy metal mobility. Environ. Int. 2001, 26, 389-394. [CrossRef]

41. Eriksson, N.; Destouni, G. Combined effects of dissolution kinetics, secondary mineral precipitation, and preferential flow on copper leaching from mining waste rock. Water Resour. Res. 1997, 33, 471-483. [CrossRef]

42. Pellegrini, S.; Garcia, G.; Penas-Castejon, J.M.; Vignozzi, N.; Costantini, E.A.C. Pedogenesis in mine tails affects macroporosity, hydrological properties, and pollutant flow. CATENA 2016, 136, 3-16. [CrossRef]

43. Anderson, M.; Ferguson, J.; Gavis, J. Arsenate adsorption on amorphous aluminium hydroxide. J. Colloid Interface Sci. 1976, 54, 391-399. [CrossRef]

44. Pierce, M.L.; Moore, C.B. Adsorption of arsenite and arsenate on amorphous iron hydroxide. Water Res. 1982, 16, 1247-1253. [CrossRef]

45. Ladeira, A.C.Q.; Ciminelli, V.S.T. Adsorption and desorption of arsenic on an oxisol and its constituents. Water Res. 2004, 38, 2087-2094. [CrossRef]

46. Kim, J.Y.; Davis, A.P.; Kim, K.W. Stabilization of available arsenic in highly contaminated mine tailing using iron. Environ. Sci. Technol. 2003, 37, 189-195. [CrossRef]

47. DeSisto, S.L.; Jamieson, H.E.; Parsons, M.B. Arsenic mobility in weathered gold mine tailings under a low-organic soil cover. Environ. Earth Sci. 2017, 76, 773. [CrossRef]

48. Beiyuan, J.; Li, J.S.; Tsang, D.C.W.; Wang, L.; Poon, C.S.; Li, X.D.; Fendorf, S. Fate of arsenic before and after chemical enhanced washing of an arsenic containing soil in Hong-Kong. Sci. Total Environ. 2017, 599-600, 679-688. [CrossRef]

49. Juhasz, A.L.; Smith, E.; Weber, J.; Naidu, R.; Ress, M.; Rofe, A.; Kuchel, T.; Sansom, L. Effect of soil ageing on in vivo arsenic bioavailability in two dissimilar soils. Chemosphere 2008, 71, 2180-2186. [CrossRef]

50. Fayiga, A.O.; Ma, L.Q. Arsenic uptake by two hyperaccumulator ferns from four arsenic contaminated soils. Water Air Soil Pollut. 2005, 168, 71-89. [CrossRef]

51. Kim, W.I.; Kim, J.J.; Yoo, J.H.; Kim, J.Y.; Kee, J.H.; Paik, M.K.; Kim, R.Y.; Im, G.J. Arsenic fractionation and bioavailability in paddy soils near closed mines in Korea. Korea J. Soil Sci. Fertil. 2010, 43, 914-922.

52. Thomas, G.W.; Hargrov, W.L. The chemistry of soil acidity. In Soil Acidity and Liming, 2nd ed.; Adams, F., Ed.; ASA Monogr 12; ASA: Madison, WI, USA, 1984.

53. Corwin, D.L.; David, A.; Goldberg, S. Mobility of arsenic in soil from the rocky mountain arsenal area. J. Contam. Hydrol. 1999, 39, 35-58. [CrossRef]

54. Dowdle, P.R.; Laverman, A.M.; Oremland, R.S. Bacterial dissimilatory reduction of arsenic (V) to arsenic (III) in anoxic sediments. Appl. Environ. Microbiol. 1996, 62, 1664-1669. [CrossRef] [PubMed]

(C) 2020 by the authors. Licensee MDPI, Basel, Switzerland. This article is an open access article distributed under the terms and conditions of the Creative Commons Attribution (CC BY) license (http://creativecommons.org/licenses/by/4.0/). 